\title{
Dry cow therapy with a non-antibiotic intramammary teat seal - a review
}

\author{
Fiona Crispie, ${ }^{1,2}$ James Flynn, ${ }^{2}$ R. Paul Ross, ${ }^{1,3}$ Colin Hill ${ }^{4,3}$ and William J. Meaney ${ }^{2}$ \\ ${ }^{1}$ Teagasc, Dairy Products Research Centre, Moorepark, Fermoy, Co Cork, \\ ${ }^{2}$ Teagasc, Dairy Production Research Centre, Moorepark, Fermoy, Co Cork, \\ ${ }^{3}$ Alimentary Pharmabiotic Centre, University College Cork, \\ ${ }^{4}$ Department of Microbiology, University College Cork.
}

Dry cow antibiotic therapy is used to eliminate existing intramammary infections and to prevent new infections in the dry period. It is implemented as part of a total management system known as the 'Five-Point Plan' for mastitis control. Recent public concerns over the widespread prophylactic use of antibiotics, coupled with an increasing interest in organic farming, have lead to a re-evaluation of the treatment of cows at drying-off. As a result, attention has focussed on the use of novel alternatives to antibiotic therapy at the end of lactation. One such therapy involves the application of a non-antibiotic bismuth-based intramammary teat seal designed for use in cows with low cell counts at the end of lactation. Like the keratin plug that forms naturally in teats of cows that have been dried-off, teat seal forms a physical barrier to invading pathogens. To date, a number of independent studies have shown that teat seal is as effective as traditional dry cow antibiotic products in preventing the occurrence of new infection during the dry period in cows with somatic cell counts of $\leq 200,000$ cells $\mathrm{ml}^{-1}$ at drying-off. This paper reviews the efficacy of teat seal in preventing dry period mastitis in both conventional and organic dairying systems.

Irish Veterinary Journal

Volume 57: 4I2-4I8, 2004

\section{Introduction}

Mastitis continues to be one of the greatest problems faced by the dairy industry. Over 137 different organisms have been identified as being causative agents of bovine mastitis, including bacteria, viruses, mycoplasma, yeasts and algae (Watts, 1988). However, most of the mastitis cases in the UK and Ireland are caused by one of the following bacterial pathogens: Escherichia coli, Staphylococcus aureus, Streptococcus uberis, Strepococcus dysgalactiae and Streptococcus agalactiae (Bradley, 2002). Mastitis continues to be the most economically important disease of dairy cattle, due to the expense of antibiotic treatment, along with the associated costs of decreased milk production and decreased fertility or, in cases where antibiotic treatment is ineffective, culling or death (Bradley, 2002). Indeed, mastitis is believed to be the most common cause of death amongst lactating cows, with a death rate of $0.6 \%$ (Bradley and Green, 2001). Overall, clinical mastitis has been

Corresponding author:

W.J. Meaney

Teagasc Dairy Production Centre,

Moorepark, Fermoy, Co Cork,

Republic of Ireland.

Tel: +3532542285

Fax: +3532542340

E-mail: bmeaney@moorepark.teagasc.ie estimated to cost the UK dairy industry $£ 168$ million annually (Bradley, 2002) and the worldwide costs have been estimated to be $\$ 1.5$ to $\$ 2.0$ billion per annum (Wells et al., 1998).

Although about 20 to $35 \%$ of clinical mastitis cases are of unknown aetiology (Wellenberg et al., 2002), it is widely accepted that bovine mastitis is mainly bacterial in origin. It can be classified as contagious or environmental (Blowey and Edmondson, 1995). In the former case, it is caused by organisms such as $S$. aureus, Strep. dysgalactiae and Strep. agalactiae, which are all adapted to survive in the udder, causing subclinical infections. Environmental pathogens such as Strep. uberis or enterobacteriaciae like E. coli are not welladapted to survive within the udder and, instead, they multiply rapidly following invasion, evoke a swift immune response and are eliminated (Bradley, 2002).

The advent of antibiotics in the 1940s led to hopes that mastitis would be eradicated quickly and easily. However, it was not

\begin{tabular}{|ll|}
\hline \multicolumn{2}{|l|}{ Abbreviations } \\
DCT & dry cow therapy \\
DIM & days in milking \\
GRAS & generally regarded as safe \\
IMI & intramammary infection \\
SCC & somatic cell count \\
TS & teat seal \\
\hline
\end{tabular}


until the 1960s, following the introduction of a 'Five-Point Plan' developed initially in the UK (Smith et al., 1967), that any success was achieved in the control of clinical and subclinical mastitis (Berry and Hillerton, 2002a). The plan suggested that control of the disease could be achieved by using the following five strategies:

- Routine maintenance of milking machines.

- Post-milking teat disinfection.

- Rapid identification and treatment of clinical cases.

- Routine whole herd antibiotic dry cow therapy.

- Culling of chronically infected cows.

More recently, EU milk hygiene directives imposed strict limits on the somatic cell count (SCC) of bulk tank milk and they have ensured that the guidelines laid down in the Five-Point Plan are followed, improving milk quality and production (Berry and Hillerton, 2002a; Bradley, 2002). While there have been enormous improvements in milk quality, recent evidence suggests that the frequency of mastitis due to environmental pathogens or to minor pathogens like coagulase-negative staphylococci and Corynebacterium bovis is increasing rapidly (Schukken et al., 1989; Myllys et al., 1998). These data, allied with increasing consumer fears over the widespread and often indiscriminate use of antibiotics, have lead to the conclusion amongst many people working in the dairy industry (including those engaged in research on mastitis) that a re-assessment of existing treatments and development of novel treatments are essential, if current standards are to be improved or even maintained.

\section{Factors predisposing to mastitis}

Several factors have conspired to ensure that mastitis has not been completely controlled to date. Firstly, in the dairy industry emphasis is often placed on breeding cows for increased milk production (Burton et al., 2001). A negative correlation exists between milk production capacity and resistance to mastitis; this is attributed, in part, to the increased metabolic stresses associated with the synthesis and secretion of milk (Pyöräla, 2002). The nutritional status of the cow is also an important factor in determining susceptibility to infections: deficiencies of selenium, copper, zinc or vitamin E levels can predispose the cow to infection (Pyöräla, 2002). Milking machines are often the cause of problems, as they can induce changes in the width of the teat duct, increasing the risk of colonisation of the teat duct and new intramammary infections (Pyöräla, 2002). Invasion by environmental pathogens such as Strep. uberis and E. coli almost certainly occurs at or soon after milking or if there is any teat damage. Surprisingly, even though animal husbandry practices have improved greatly, there has been no reduction in the number of environmental infections. Probably the greatest problem in treating mastitis is the plethora of pathogens that can cause mastitis - if protection or immunity is enhanced against one pathogen, it doesn't protect against another (Sordillo and Streicher, 2002).

\section{Dry cow therapy}

During the dry period (i.e., the time between the last milking of one lactation and calving at the start of the next), the mammary gland undergoes a series of changes that influence the cow's resistance to bacterial infection. Even the length of the dry period can affect udder health (Green et al., 2002). Additionally, it is well known that the presence of infection during the dry period can have profound effects on cow health and productivity after calving, often resulting in decreased milk yield and milk of poor quality from the infected quarters. Dry period infections may have persisted from the previous lactation or they may be new infections acquired during the dry period. Indeed, new infections during the dry period have been shown to occur at up to 10 times the rate of new infections during lactation, with E. coli or Strep. uberis being the most common causative agents. However, clinical mastitis is rare during the dry period, probably due to high concentrations of lactoferrin and leucocytes in the mammary gland at this time. Nonetheless, while dry period infections may not present as clinical cases during the dry period, there is a high risk that subclinical cases will become clinical after calving (Green et al., 2002).

\section{Antibiotic therapy}

The use of antibiotics for the treatment of mastitis in the 1950s led to the development of dry cow therapy (Bramley and Dodd, 1984). It is used to eliminate existing intramammary infections (IMI) and to prevent new infections during the dry period (Bramley and Dodd, 1984). Ideally, dry cow therapy will achieve high initial concentrations of antibiotic throughout the udder, resulting in a swift kill of existing pathogens, followed by a prolonged period of release of the antibiotic to prevent new infections (Green et al., 2002). The antibiotic should then be readily milked out following calving. While normally very effective, dry cow antibiotic therapy has some disadvantages, including the appearance of residues in the milk when treated cows calve. As a result, milk is normally withheld for a period of time following calving, with concomitant economic losses (Craven, 1987). Additionally, there is mounting concern over the indiscriminate overuse of antibiotics, as it may contribute to the alarming increase in resistance to antibiotics that many microorganisms have evolved (WHO, 1994). Such claims have been fiercely debated. Even after 30 years of use, resistance to cloxacillin has not been detected in bovine isolates of $S$. aureus (Booth, 1997). Regardless of the concerns, or their veracity, dry cow antibiotic therapy remains a cornerstone of mastitis treatment.

Limiting therapy to infected cows or to infected quarters (selective dry cow therapy) is one method by which the use of antibiotics is reduced (Bratlie, 1972; Browning et al., 1990). However, several investigations have shown that the incidence of new intramammary infections increases when uninfected dry cows are left untreated. A recent study by Berry and Hillerton (2002a) compared the effects of dry cow treatment and no 


\section{peer reviewed}

treatment on the incidence of new IMIs and clinical mastitis within two low-cell-count herds and two herds undergoing conversion to organic farming. They demonstrated that there was a significant reduction in the incidence of clinical mastitis during the dry period in cows that had been treated with an antibiotic when compared to untreated cows (Berry and Hillerton, 2002a). In addition, there were also significantly more IMIs present at calving in the untreated groups in all four herds. Fifty per cent of new infections that occurred at calving were caused by $S$. aureus, a microorganism that is particularly difficult to treat effectively with antibiotics (Berry and Hillerton, 2002a). Thus, it appears that antibiotic treatment is necessary during the dry period, unless new alternatives can be developed (Berry, 2002; Berry and Hillerton, 2002a).

\section{Teat seals}

A keratin plug forms naturally in the teat canal after drying-off and appears to be a major defensive mechanism against infection. It has been reported that the rate of closure of teat canals after drying-off varies greatly from cow to cow (Williamson et al., 1995), with 50\% of teats still 'open' 10 days after drying-off. This delay may lead to an increase in new infections, as $97 \%$ of clinical dry period IMIs occur in open quarters (Williamson et al., 1995). Thus, the concept of using artificial teat seals as a barrier to prevent new IMIs was developed. Given the current public concerns over the blanket use of antibiotics in farm animals, it is hardly surprising that the idea of using teat seals as a prophylactic treatment for mastitis has gained popularity. Quarters with external seals have been shown to have a lower level of new IMI during the dry period than do unsealed quarters, but the existing external seals are ineffective as a long-term treatment (Leslie et al., 1999; Hemling et al., 2000). Much greater success has been achieved with internal seals. A teat seal containing bismuth subnitrate was developed in the 1970s and was shown to be effective at preventing new dry period infections in an artificial challenge study (Meaney, 1977). This product resulted in a $90 \%$ reduction of new IMI during the dry period, and remained lodged in the lower teat for at least three to four weeks following drying-off (Figure 1). Subsequently, a commercial combination product comprised of a short-acting antibiotic and a bismuth subnitrate seal was developed and has been available in Ireland since that

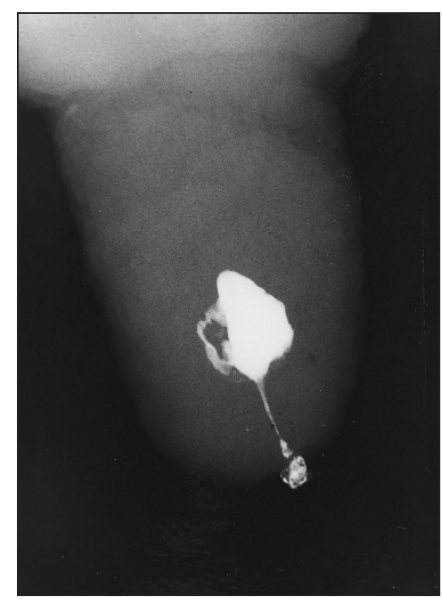

Figure I. X-ray plate illustrating the appearance and position of teat seal in the teat sinus, teat canal, and teat orifice. abundance of new antibiotics developed in the 1970s resulted in limited interest in the use of internal teat seals, despite promising results obtained with their use (Meaney, 1977).

Efficacy of teat seal in cows with low cell counts

Recently, a reformulated version of the seal (Teatseal; Bimeda (NZ) Ltd., Auckland, New Zealand) was examined for its ability to prevent the development of new IMIs during the dry period and of clinical mastitis during the following lactation (Woolford et al., 1998). Four weeks before drying-off, cows were screened on the basis of SCC and bacteriology. Only cows with an SCC of $<200,000$ cells $/ \mathrm{ml}$ and with at least three uninfected quarters were chosen as experimental subjects. Thus, the final selection comprised 528 cows. A within-udder design was then used wherein the rate of new IMIs was compared between adjacent quarters of each cow. This ensured that treatments were evaluated within each cow selected for the study. Udder quarters were treated at drying-off with one of the following treatments: 505 quarters with teat seal (TS: "Teatseal"; Bimeda NZ Ltd); 505 quarters with TS plus antibiotic $(600 \mathrm{mg}$ benzathine cloxacillin in an aqueous base, Osmonds "Teatseal 1", CrossVetpharm Group, followed immediately by an infusion of teat seal); 528 quarters with antibiotic $(250 \mathrm{mg}$ cephalonium: Cepravin Dry Cow; Mallinkrodt Veterinary Ltd, Wellington, New Zealand) alone and $\mathbf{5 2 8}$ quarters served as untreated controls. Relative to the control group, the three groups that received an infusion of TS, TS plus antibiotic or antibiotic only showed a 10 -fold reduction in new clinical IMIs during the dry

TABLE I: Number of new intramammary infections (IMls) over the dry period and at calving in udder quarters of untreated cows (negative control) and of cows treated with a dry cow antibiotic (positive control), teat seal, or teat seal plus antibiotic (Adapted from Woolford et al., I998)

\begin{tabular}{lcccc} 
Experimental group & Negative control & Positive control & Teat seal & Teat seal + antibiotic \\
\hline Total quarters treated & 528 & 528 & 505 & 505 \\
\hline New dry period clinical IMIs & 18 & $2^{*}$ & $1^{*}$ & $2^{*}$ \\
\hline New IMIs at calving & 67 & $12^{*}$ & $12^{*}$ & $13^{*}$ \\
\hline Total new IMIs & 85 & $14^{*}$ & $2.5^{*}$ & $10^{*}$ \\
\hline$\%$ of quarters infected & 16.1 & $2.7^{*}$ & $2.0^{*}$ \\
\hline
\end{tabular}


period. A similar reduction was seen in the incidence of new IMIs at calving. The infusion of an antibiotic together with the seal did not achieve any extra reduction in new IMIs (Woolford et al., 1998); the quarters treated with antibiotic had approximately the same level of infection in the dry period and at calving as the other two treated groups (Table 1 ). The incidence of new clinical mastitis in the first two months of lactation was similar in the three treated groups (Woolford et al., 1998). Importantly, the seal appeared to remain lodged in the teat canal for up to 100 days of the dry period and was particularly effective at reducing the incidence of infection caused by Strep. uberis, the predominant mastitis-causing organism in New Zealand (Woolford et al., 1998). Thus, these authors concluded that teat seal was as effective as a long-acting antibiotic in preventing mastitis both during the dry period and during the first 60 days of lactation.

A similar independent study (Huxley et al., 2002). was undertaken in the UK where the efficacy of a dry cow antibiotic containing cephalosporin was compared to teat seal. The cows chosen for this study did not have any sign of clinical disease, had four functioning quarters, and had been free of antiinflammatory and antibiotic treatment for at least 30 days.

TABLE 2: Number of IMls acquired during the dry period, listed by causative organism (Adapted from Huxley et al., 2002)'.

\section{Causative organism}

\section{Group A \\ (Teat seal) \\ No of}

quarters $=928$

\section{Coagulase-positive}

staphylococci

Streptococcus spp.

Escherichia coli

All enterobacteriaceae

All major pathogens

All minor pathogens

${ }^{1}$ Numbers within rows marked with * differ significantly $(\mathrm{p}<0.01)$ between treatments.

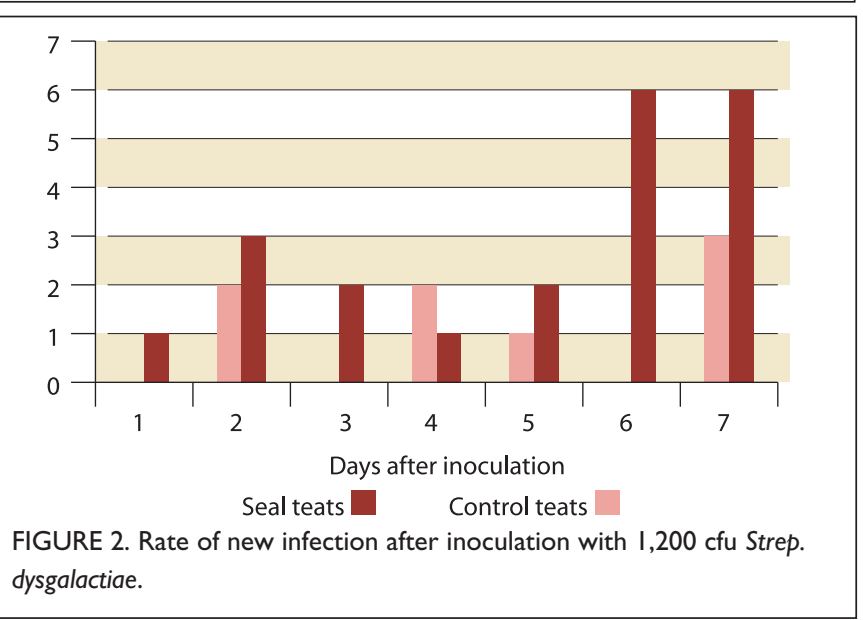

Additionally, the selection process specified a SCC level of $\leq 200,000$ cells $/ \mathrm{ml}$ and freedom from clinical mastitis in the preceding lactation. Using these criteria, 605 cows were selected for the study: of these, 252 were infused with teat seal (Cross Vetpharm Group Ltd., Ireland) and 253 with a long-acting antibiotic preparation $(250 \mathrm{mg}$ cephalonium, Cepravin Dry Cow, Schering Plough Ltd. UK).

Subsequently, data for dry period IMI were available from 467 quarters (232 teat seal and 235 antibiotic) and data for clinical mastitis were available from 479 quarters (237 teat seal and 242 antibiotic). The results showed that quarters treated with teat seal acquired significantly fewer IMI caused by $E$. coli, by all enterobacteriaceae and by all major pathogens combined during the dry period (Table 2). Despite the significantly greater number of new infections acquired by cows treated with the antibiotic, there was not a significant increase in the development of clinical mastitis in these quarters in the first 100 days of lactation (Huxley et al., 2002). Thus, under UK field conditions, an internal seal was proven to be as effective as an antibiotic, again highlighting the potential of this novel therapy as an effective alternative to antibiotic treatment (Huxley et al., 2002).

In a third study, the efficacy of teat seal in preventing infection following an artificial challenge with Strep. dysgalactiae was evaluated by Meaney et al. (unpublished data). In this study, 62 infection-free udder quarters in 17 dairy cows were selected at drying-off. Following the last milking of lactation, 31 quarters were infused with teat seal and the remaining 31 were used as untreated controls. Three days after infusion, all teats were inoculated with 1,200 cfu of Strep. dysgalactiae into the teat canal to a depth of $17 \mathrm{~mm}$. The cows were then observed over the next seven days for signs of clinical mastitis. During this period, 20 clinical cases of mastitis developed in the untreated quarters and eight in the quarters infused with teat seal (Table 3 ). Additionally, new infections appeared more rapidly in untreated teats than in those infused with teal seal (Figure 2). These data indicate that teat seal provided significant protection $(\mathrm{p}=0.002)$ against an artificial challenge with Strep. dysgalactiae, supporting the studies using natural challenge (Woolford et al., 1998; Huxley et al., 2002).

\section{Efficacy of teat seal in infected cows}

In the studies described above, teat seal was shown to successfully prevent new infections during the dry period both from experimental challenge and from natural exposure (Meaney, 1977; Woolford et al., 1998; Huxley et al., 2002).

TABLE 3: New infections in sealed teats and in unsealed teats of non-lactating cows after inoculation with $1,200 \mathrm{cfu}$ S. dysgalactiae.

\begin{tabular}{llcc} 
Treatment & Quarters (n) & $\begin{array}{l}\text { No. of } \\
\text { new } \\
\text { infections }\end{array}$ & \% new infections \\
Untreated & 31 & 20 & 65 \\
\hline Seal & 31 & 8 & 26 \\
\hline
\end{tabular}




\section{peer reviewed}

\begin{tabular}{|c|c|c|c|c|}
\hline \multirow[b]{3}{*}{ No. of quarters at risk } & \multicolumn{2}{|c|}{ New clinical cases in dry period } & \multicolumn{2}{|c|}{ New IMI at calving } \\
\hline & Seal & Untreated & Seal & Untreated \\
\hline & 784 & 812 & 784 & 799 \\
\hline No. of new infections & $0^{\mathrm{a}}$ & $10^{\mathrm{b}}$ & $27^{\mathrm{c}}$ & $93^{d}$ \\
\hline
\end{tabular}

However, all of the cows in the experiments had low cell counts. This raised the question: would teat seal be equally effective in preventing clinical mastitis in the dry period in cows already infected at drying-off? To address this question, seven dairy herds were recruited for a selective teat seal trial. The herds included two standard dairy herds, two fully commercial organic herds and three herds undergoing conversion to organic status (Berry and Hillerton, 2002b). Uninfected udder quarters of cows in all seven herds were randomly assigned to either teat seal or no treatment (control). Additionally, infected udder quarters in cows in four of the seven herds were also randomly assigned to teat seal or no treatment. Samples were taken from the 398 cows in the trial at one week prior to drying-off, at drying-off, at calving, and approximately one week after calving. As a result of the randomisation process, there were no significant differences in distribution for infection status between the two treatment groups at drying-off. There was, however, a significant difference in the infection status at calving between the two groups $(\mathrm{p}=0.001)$, as cows treated with teat seal were 0.27 times less likely to have a new infection at calving than untreated cows (Berry and Hillerton, 2002b). There was also a statistically significant difference in the incidence of clinical mastitis during the dry period. Clinical symptoms were detected in 10 quarters from the untreated group and there was no clinical case in the group treated with teat seal $(\mathrm{p}=0.001$; Berry and Hillerton, 2002b). Again, at calving, the untreated quarters had significantly more new IMI that the treated group (93 and 27 quarters, respectively; $\mathrm{p}<0.001$ ), although the incidence of the predominant organism causing the new infections, Strep. uberis, did not differ between the groups (Table 4). Of the total quarters that were infected at calving, more cases of clinical mastitis arose in the untreated group than in the treated group $(p<0.001)$. Overall, however, the percentage of quarters that developed clinical mastitis in this period did not differ between groups. Thus, the efficacy of teat seal was demonstrated against a variety of environmental challenges, which included cows with a range of cell counts and infections, in both winter housing and summer grazing environments (Berry and Hillerton, 2002b).

\section{Teat seals and udder hygiene}

Bismuth-based teat seals are biologically inert and the introduction of an internal seal without antibacterial properties into the mammary gland is not risk-free. Undoubtedly, pathogens may be accidentally introduced into the quarter during infusion, or the seal itself may become contaminated, leading to infection. The importance of using teat seal in a hygienic manner and of abiding strictly to the manufacturer's instructions was highlighted recently when a cow in a dairy herd of 150 cows died due to a pseudomonas infection. A subsequent investigation of the sanitary conditions on the farm revealed that tubes of the teat seal (Orbeseal, Pfizer) were stored in a bucket containing water contaminated with Pseudomonas aeruginosa (Milnes and Platter, 2003). This consequently led to an outbreak of gangrenous mastitis and, subsequently, the death of one cow. Thus, many farmers may have more confidence in the product if an antibiotic is also incorporated into the treatment. Godden et al. (2003) studied the effectiveness of using an internal teat seal with an antibiotic to prevent the acquisition of new dry period IMIs in a North American herd. In order to qualify as eligible for this trial, cows had to have four functional quarters free of clinical mastitis on the day of drying off. Additionally, it was specified that the cows must not have received parenteral or intramammary antibiotic or anti-inflammatory treatment for at least 30 days prior to drying-off. A total of 419 cows were thus selected. Following the final milking, all four quarters were treated with a commercial long-acting dry cow antibiotic (Orbenin DC; Cloxacillin (benzathine), 500mg, Schering Plough Corp., Kenilworth, N.J.). Teat seal (Orbeseal, Pfizer Animal Health, $\mathrm{NY}$ ) was then randomly assigned to two contralateral quarters ( $\mathrm{LH} / \mathrm{RF}$ or $\mathrm{LF} / \mathrm{RH})$ within each cow. The alternate two contralateral quarters served as controls. The seals were removed at the first milking of the new lactation and all quarters were sampled for culture and SCC analysis (Godden et al., 2003). Samples were taken at drying-off, once between one and three days in milking (DIM) and once between six and eight DIM. The proportion of quarters with an IMI present between drying-off and the first three days of the new lactation was $29.1 \%$ for the control group (antibiotic only) versus $22.8 \%$ for the treated group (teat seal plus antibiotic) - a statistically significant difference $(\mathrm{p}<0.05)$. Similarly, between six and eight DIM the proportions of quarters with an IMI were significantly different $(\mathrm{p}<0.05)$ at $25.9 \%$ for the control group versus $20.6 \%$ for the treated group. Thus, quarters treated with Orbeseal had a significantly lower prevalence of IMI caused by all major and minor pathogens, including environmental streptococci, for the first six days of the new lactation (Table 5; Godden et al., 2003). Similarly, treatment with Orbeseal was associated with a significant reduction in the risk of developing a new IMI either from a major pathogen or from environmental streptococci. 


\begin{tabular}{|l|lll}
\hline TABLE 5: Prevalence of IMI in control (antibiotic only) and treated (seal plus antibiotic) quarters at drying off, I to 3 days in milking (DIM) and 6 to 8 DIM \\
(Adapted from Godden et al., 2003).
\end{tabular}

Finally, the proportion of quarters experiencing a clinical mastitis event between drying-off and up to Day 60 of the new lactation was significantly lower $(\mathrm{p}<0.05)$ for treated quarters (5.9\%) than for control quarters $(8.0 \%)$ Thus, in some instances, addition of antibiotic to teat seal may increase its efficacy and safety (Godden et al., 2003). The additional protective effect observed by using teat seal plus antibiotic over antibiotic alone may be due to several factors. Firstly, the seal offers a barrier to bacterial entry in the early dry period when the keratin seal may not have formed properly. Secondly, in the late dry period, when the concentration of antibiotic may have fallen below therapeutic levels, the seal persists in its barrier function. Finally, throughout the entire dry period, teat seal provides a barrier against many bacterial species that may be insensitive to the antibiotic being used (Godden et al., 2003).

\section{Discussion}

Dry cow therapy was originally developed with the aim of controlling summer mastitis. Its use was rapidly extended to routine use on all cows all year round. More recently, however, the emphasis has changed and in the majority of dairy herds the primary function of DCT is the prevention of new IMIs rather than the treatment of existing IMIs. This is due in part to an increase in organic dairy farming, and also due to attempts to reduce costs in response to lower milk prices. Additionally, in the world of improved milk quality and better udder health one has to question the necessity to treat all cows, irrespective of cell count. Restricted or selective use of dry cow antibiotics would appear to be a good compromise for those concerned about treating cows that do not have intramammary infections at drying-off. Only those cows with an infected gland would be treated, whether in the infected quarter only or in all quarters; in this way, the use of antibiotics would be both targeted and discriminate. Selective dry cow therapy of this type has been shown to be as effective as complete therapy in eliminating existing infections; however, there is still a problem with new infections arising during the dry period. Additionally, selecting treatments at the quarter level proves difficult while infected cows have to be identified quickly, cheaply and accurately. Cell counts, CMT analysis or $\mathrm{N}$-acetyl- $\mathrm{B}-\mathrm{D}$-glucosaminidase (NAGase) tests are sometimes used as confirmatory tests. Bacteriological sampling, however, remains the definitive method of identifying infected quarters and, as this method is both time-consuming and costly, it poses a drawback to selective dry cow therapy. To lower the incidence of mastitis in a herd where selective dry cow therapy is practised, it is necessary to cull older infected cows and prevent new IMI in the younger cows. To this end, teat seal provides an attractive adjunct to both selective and blanket dry cow therapy.

Enhancement of teat sealing formulations may be achieved using non-antibiotic additives like bacteriocins, which are proteins produced by some bacteria that have the ability to kill other organisms (Ryan et al., 1998, 1999; Twomey et al., 2000). Veterinary products used for the treatment or prevention of disease in animals whose tissues and/or products are destined for human consumption may give rise to unwanted or harmful residues. Thus, to maintain consumer confidence, international bodies such as the European Agency for the Evaluation of Medicinal Products (EMEA), Codex Alimentarius and the Food and Drug Administration (FDA) help to evaluate risks and oversee laws relating to the levels and type of residues in milk and dairy products. A non-antibiotic anti-mastitis dry cow formulation containing a bacteriocin derived from a GRAS organism could be of immense benefit to the dairy sector in meeting the rigorous standards imposed by these bodies. Combining the seal with a broad-spectrum bacteriocin provides the physical barrier effect and it localises the anti-microbial inhibitor in the teat sinus. Since the efficacy of the teat seal in preventing mastitis is not dependent on anti-microbial activity throughout the complete mammary gland, then the amount of bacteriocin required per seal treatment will be small relative to antibiotic usage with conventional dry cow therapy. The efficacy of incorporating the bacteriocin lacticin 3147 into teat seal will be reviewed elsewhere (Crispie et al., manuscript in preparation).

\section{Conclusion}

Teat seal has been shown to provide a safe, effective alternative to the blanket use of antibiotics at drying-off. Used on its own, teat seal has been shown to be as effective as a long-acting antibiotic in controlling the rate of new infection during the dry period. Importantly, the incorporation of antibiotics or other suitable antimicrobials into teat seal could prevent inadvertent contamination during infusion, thus improving the safety of the product for the untrained user. 


\section{References}

Berry, E.A. (2002). To dry treat or not? Proceedings of the British Mastitis Conference, Shepton Mallet., pp37-43.

Berry, E.A. and Hillerton, J.E. (2002a). The effect of selective dry cow treatment on new intramammary infections. Journal of Dairy Science 85: 112-121.

Berry, E.A. and Hillerton, J.E. (2002b). The effect of an intramammary teat seal on new intramammary infections. Journal of Dairy Science 85: 2512-2520.

Blowey, R.W. and Edmondson, P.W. (1995). Mastitis control in dairy herds. Farming Press (Ipswich), pp.29.

Booth, J.M. (1997). Progress in mastitis control - an evolving problem. Proceedings of the British Mastitis Conference, Stoneleigh, pp3-9.

Bradley, A.J. (2002). Bovine mastitis: an evolving disease. Veterinary Journal 164: 116-128.

Bradley, A.J. and Green, M.J. (2001). A study of the incidence and significance of Gram-positive infections acquired during the dry period under UK field conditions. Proceedings of the 40th Annual Meeting of the National Mastitis Council, Reno, Nevada, pp185-186. Madison, WI: National Mastitis Council.

Bramley, A.J. and Dodd, F.H. (1984). Reviews of the progress of dairy science: Mastitis control - progress and prospects. Journal of Dairy Science 51: 481-512.

Bratlie, O. (1972). Dry cow therapy. Nordisk Veterinärmedizin 24: 433-439.

Browning, J.W., Mein, G.A., Barton, M., Nicholls, T.J. and Brightling, P. (1990). Effects of antibiotic therapy at drying-off on mastitis in the dry period and early lactation. Australian Veterinary Journal 67: 440-442.

Burton, J.L., Madsen, S.A., Yao, J., Sipkovsky, S.S. and Coussens, P.M. (2001). An immunogenomics approach to understanding periparturient immunosuppression and mastitis susceptibility in dairy cows. Acta Veterinaria Scandinavica 42: 407-424.

Craven, N. (1987). Efficacy and financial value of antibiotic treatment of bovine clinical mastitis during lactation- a review. British. Veterinary Journal 143: 412-422.

Godden, S., Rapnicki, P., Stewart S., Fetrow, J., Johnson, A., Bey, R. and Farnsworth, R. (2003). Effectiveness of an internal teat sealant in the prevention of new intramammary infections during the dry and early-lactation periods in dairy cows when used with an intramammary antibiotic Journal of Dairy Science 86: 3899-3911.

Green, M.J., Green, L.E., Medley, G.F., Schukken, Y.H. and Bradley, A.J. (2002). Influence of dry period bacterial intramammary infection on clinical mastitis in dairy cows. Journal of Dairy Science 85: 2589-2599.

Hemling, T., Henderson, M., Leslie, K.E., Lim, G.H. and Timms, L.L. (2000). Experimental models for the evaluation of the adherence of dry cow teat sealants. Proceedings of 39th Annual Meeting National Mastitis Council. Atlanta, Georgia, pp248-249. Madison, WI: National Mastitis Council.

Huxley, J.N., Green, M.J., Green, L.E. and Bradley, A.J. (2002). Evaluation of the efficacy of an internal teat sealer during the dry period. Journal of Dairy Science 85: 551-561.

Leslie, K.E., Day, K.J., TenHag, J., Kelton, D.F. and Kerbler, T.L. (1999). Factors affecting the adherence of a dry cow sealant.
Proceedings of 38th Annual Meeting, National Mastitis Council. Arlington, Virginia, ppl36-137. Madison, WI: National Mastitis Council.

Meaney, W.J. (1977). Effect of a dry period teat seal on bovine udder infection. Irish Journal of Agricultural Research 16: 293-299.

Milnes, A. and Platter, P. (2003). Gangrenous mastitis in a dairy herd. Veterinary Record 153: 635.

Myllys, V., Asplund, K., Brofeldt, E., Hirvelä-Koski, V., Honkaren-Bazalski, T., Juntilla, J., Kulkas, L., Myllykangas, O., Niskanen, M., Saloniemi, H., Sandholm, M. and Saranpää, T. (1998). Bovine mastitis in Finland in 1988 and 1995 - changes in prevalence and antimicrobial resistance. Acta Veterinaria Scandinavica 39: 119-126.

Pyörälä, S. (2002). New strategies to prevent mastitis. Reproduction in Domestic Animals 37: 211-216.

Ryan, M., Meaney, W.J., Ross, R.P. and Hill, C. (1998). Evaluation of lacticin 3147 and a teat seal containing this bacteriocin for inhibition of mastitis pathogens. Applied and Environmental Microbiology 64: 2287-2290.

Ryan, M.P., Flynn, J., Hill, C., Ross, R.P. and Meaney, W.J. (1999). The natural food grade inhibitor, lacticin 3147, reduced the incidence of mastitis after experimental challenge with Streptococcus dysgalactiae in nonlactating dairy cows. Journal of Dairy Science 82: 2625-2631.

Schukken, Y., Van de Geer, D., Grommers, F., Smith, J. and Brand, A. (1989). Intramammary infections and risk factors for clinical mastitis in herds with low somatic cell counts in bulk milk. Veterinary Record 125: 393-396.

Smith, A., Westgarth, D.R., Jones, M.R., Neave, F.K., Dodd, F. H. and Brander, G.C. (1967). Methods of reducing incidence of udder infection in dry cows. Veterinary Record 81: 504-510.

Sordillo, L.M. and Streicher, K.L. (2002). Mammary gland immunity and mastitis susceptibility. Journal of Mammary Gland Biology and Neoplasia 7: 135-146.

Twomey, D.P., Wheelock, A I., Flynn, J., Meaney, W.J., Hill, C. and Ross, R.P. (2000). Protection against Staphylococcus aureus mastitis in dairy cows using a bismuth-based teat seal containing the bacteriocin, lacticin 3147. Journal of Dairy Science 83: 1981-1988.

Watts, J.L. (1988). Etiological agents of bovine mastitis. Veterinary Microbiology 16: 41-46.

Wellenberg, G.L., van der Poel, W.H.M. and Van Orschot, J.T. (2002). Viral infections and bovine mastitis: a review. Veterinary Microbiology 88: 27-45.

Wells, S.J., Ott, S.L. and Hillberg Seitzinger, A. (1998). Key health issues for dairy cattle-new and old. Symposium: emerging health issues. Journal of Dairy Science 81: 3029-3035.

WHO (1994). Scientific working group on monitoring and management of bacterial resistance to antimicrobial agents. Geneva: World Health Organisation.

Williamson, J.H., Woolford, M.W. and Day, A.M. (1995). The prophylactic effect of a dry cow antibiotic against Streptococcus uberis. New Zealand Veterinary Journal 43: 228-234.

Woolford, M.W., Williamson, A.M. and Copeman, P.A.J. (1998). The prophylactic effect of a teat sealer on mastitis during the dry period and the following lactation. New Zealand Veterinary Journal 46:12-19. 